\title{
Incorporating Root Crops under Agro-Forestry as the Newly Potential Source of Food, Feed and Renewable Energy
}

\author{
a Indonesian Legume and Tuber Crops Research Institute (ILETRI) \\ Jl. Raya Kendalpayak Km 8 P.O. Box 66 Malang 65101
}

Yudi Widodo, St. A. Rahayuningsih, Nasir Saleh and Sri Wahyuningsiha

\begin{abstract}
Entering the third millennium food and energy crisis is becoming more serious in line with water scarcity amid of climate change induced by global warming, that so called as FEWS (food energy and water scarcity). In the last five decades Indonesian agricultural development of food crops had been emphasized on cereals and grains based. Conversion of forest into agricultural field in the form of upland and lowland facilitated by irrigation is prioritized for cereals such as rice, maize as well as grain legumes such as soybean, peanut etc. Unfortunately, root crops which their main yield underground are neglected. At the end of second millennium Indonesia was seriously suffered from multi-crisis economic trap, so Indonesia as part of countries under World Food Program to import the huge of food to cover domestic consumption such as rice, wheat, soybean, corn etc. On the other hand, consumption of energy was also increase significantly. These conditions triggering government to stimulate integrated agricultural enterprises for providing abundance of food as well as adequate renewable energy. Although root crops were neglected previously, however from its biological potential to produce biomass promotes root crops into an appropriate position. The variability of root crops which ecologically can be grown from upland in dry areas till swampy submergence condition. Forest conversion into agricultural land is not allowed due to forest is useful to prevent global warming. Therefore, food, feed and fuel (renewable energy) production have to be able grown under agro-forestry. Fortunately the potential of root crops has competency to meet the current need to fulfil food, feed and fuel as well as fibre under future greener environment.
\end{abstract}

Keywords: root crops, food, feed, renewable energy, agro-forestry

Article History: Received May 15, 2013; Received in revised form May 12, 2014; Accepted August 20 , 2014; Available online

How to Cite This Article: Widodo, Y., Rahayuningsih, St.A., Saleh,N., \& Wahyuningsih, S., (2014) Incorporating root crops under agro-forestry as the newly potential source of food, feed and renewable energy. Int. Journal of Renewable Energy Development, 3(3), 193-206. http://dx.doi.org/10.14710/ijred.3.3.193-206

\section{Introduction}

Food, feed, fibre, and funny shelter as well as fuel (F5) are the basic need of human crosswise civilization. Those basic needs have to be available adequately for sustaining a better civilization in the future by minimizing the detrimental effect of production and utilization into the environment (Eco Summit, 2007). Better future under greener environment is ultimate objective of the life style as so called bio economic base epoch. Although in the beginning those of F5 were produced from agricultural enterprises, however regarding to fuel by entering industrial era it was dominated by un-renewable fuel from fossil.
Subsequently exploration and exploitation through mining enterprises of fossil fuel was intensively undertaken in huge amount in attempts to cover the greater consumption of energy. Disadvantageous in exploration, exploitation, shipment, processing till utilization of fossil fuel resulting significant damage into the environment, and sometimes the accidents occur destroying environment and living things into worse circumstances. The praxis in production till utilization of fuel based on fossil seems can not be entirely executed in the future, because the limitation of fossil reserves as well as detrimental consequence to the environment, which in turn disturbing and sacrificing the supply of other F4 basic human need. Indeed from 
Citation: Widodo, Y., Rahayuningsih, St.A., Saleh,N., \& Wahyuningsih, S., (2014) Incorporating root crops under agro-forestry as the newly potential source of food, feed and renewable energy. Int. Journal of Renewable Energy Development, 3(3), 193-206, doi : 10.14710/ijred.3.3.193-206

$\mathrm{P}$ a g e | 194

the early invention Arrhenius (1859-1927) in late nineteenth century (1896) reminded that combustion of huge fossil fuel resulted to the increase of $\mathrm{CO}_{2}$ concentration into the atmosphere which ultimately influence to global warming (ice ages) as well as climate change. The statement from Arrhenius reflecting an equation about initial warning of global warming phenomenon that He was found is as follow "if the quantity of carbonic acid increases in geometric progression, the augmentation of the temperature will increase nearly in arithmetic progression" (Arrhenius, 1896). Referring to that problem, therefore alternative fuel from non fossil with renewable produced from agricultural enterprises is more preferred due to more ecologically friendly, as it was demonstrated by Rudolf Diesel (1858-1913) with peanut oil as fuel engine at Paris Expo. Unfortunately, Rudolf Diesel was found death floating in the North Sea by remaining question was his suicide or victim of assassination? Although these fuels recommended by Rudolf Diesel were not immediately popular, during 2008 rises in fuel prices, coupled with concerns about reserves, have led to more widespread use of vegetable oil and bio-diesel. The primary source of fuel remains what became known as Diesel fuel, an oil by-product derived from refinement of petroleum (Helimenstine, 2013). An enormous need to realize the technology fitting into natural harmony from the admirable legacy of previous inventors is faced into the serious challenges. Due to the current agricultural production countenances the complicated problem which is not able to nourish people sufficiently. As a result, according to GIEWS FAO (2013) there almost 1 billion people among 7.2 billion stretching over 36 countries under malnourished. Expanding agricultural field by converting forest into open field is not easily eligible due to the reason that forest is an effective instrument for reducing $\mathrm{CO}_{2}$ emission under the severely impact of global warming. Many communities around the world seeing and experiencing the harshly of climate change, in sub tropical and temperate regions flood summer as well as longer winter reduce the ability to crop production. Whereas in the tropical regions drought calamity during dry season as well as flooding during wet season and also season anomaly such as wet dry season as well as dry wet season are the problems encountered in the crop production. As consequence amid of climate change fulfilling the basic human need in the form of $\mathrm{F} 5$ become more difficult to be attained (UNFCCC, 2009). It means that in providing F5 through expansion of agricultural enterprises requires a new approach by maintaining the forest sustainability dedicated for the global community. Based on his long experience and experiments Mac Donald (1982) suggested that agroforestry is the appropriate way out to conserve the forest and avoid desertification as well as provide adequate food for arid climate such as in Africa. Widodo
(2011; 2012) indicated the success of agro-forestry implementation to harmonize the long term ecological induction and a short term economical seduction as well. Thus, retaining of forest sustainability to reduce climate change and attaining food crops production under forest can be undertaken simultaneously.

In the commencement of civilization at hunter and gathering era, human depended on natural forest then in the early agricultural era human convert forest into open agricultural field for crop production. The crops as source of food cultivated in the open agricultural field are mostly sun loving plant. However, when the failure of harvest in agricultural field was occur, people entering forest to hunter and gather the edible portion of plant and animal again. Although the agricultural trends indicated food crops propagated by seed is dominant, conversely during hunger calamity people entering forest gathering mostly of root, tuber and banana (RTB). Recently Consultative Group for International Agricultural Research (CGIAR) promotes strongly about RTB in line with cereals and grains under future harvest program.

Unlike cereals and grains the period to produce yield is clearly started at generative phase, conversely in root crops yield is initiated from early vegetative phase (Figure 1). Therefore in root crops biomass accumulated in the main yield is higher beyond the potential of yield obtained by cereals and grains. Unfortunately, according to Rhoades and Horton (1990) food consumption pattern during the last five decades was dominantly supplied by cereals and grains, because root crops which its main yield underground is considered dirty, voluminous and perishable. So, handling and processing of root crops is laborious and more difficult compared to that cereals and grains (Global Perspective Study Unit FAO, 2006). Wide range of ecological requirement of root crops from dry upland areas till swampy submergence as well as from open field till heavily shade intensity induces root crops as the appropriate food, feed, fibre, funny shelter and fuel source under future greener environment (F6GE). Accordingly adaptation, mitigation and production of root crops to meet the urgent need on F6GE can be simultaneously attained under agro-forestry as harmonious parity (Suhardjito, et al., 2003). Moreover, by developing root crops under agro-forestry conversion of forest into open agricultural field for food crops production with cereals and grain legumes based is not urgently required. Thus under agro-forestry, in a short term economical seduction in term of food as well as cash income can go along with the ecological induction (Figure 2). Hence, the major and important role of forest to absorb $\mathrm{CO}_{2}$ from atmospheric into biomass above and under ground in order to anticipate global warming will not be significantly disturbed. 


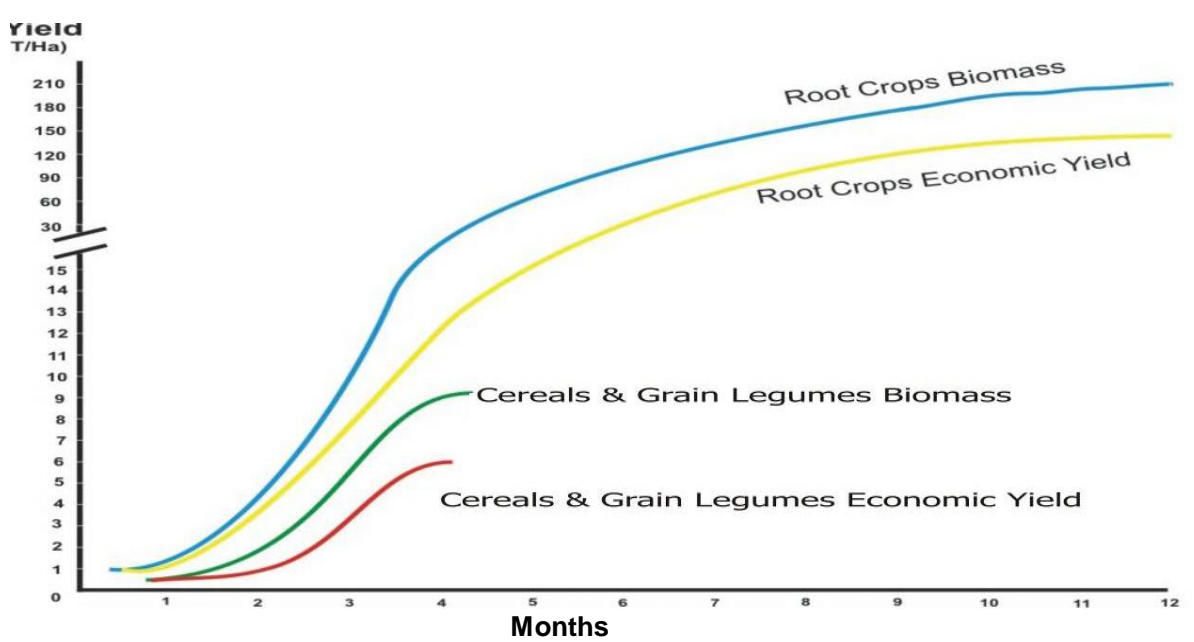

Figure 1. A difference growth pattern between cereals and grains with root and tuber crops

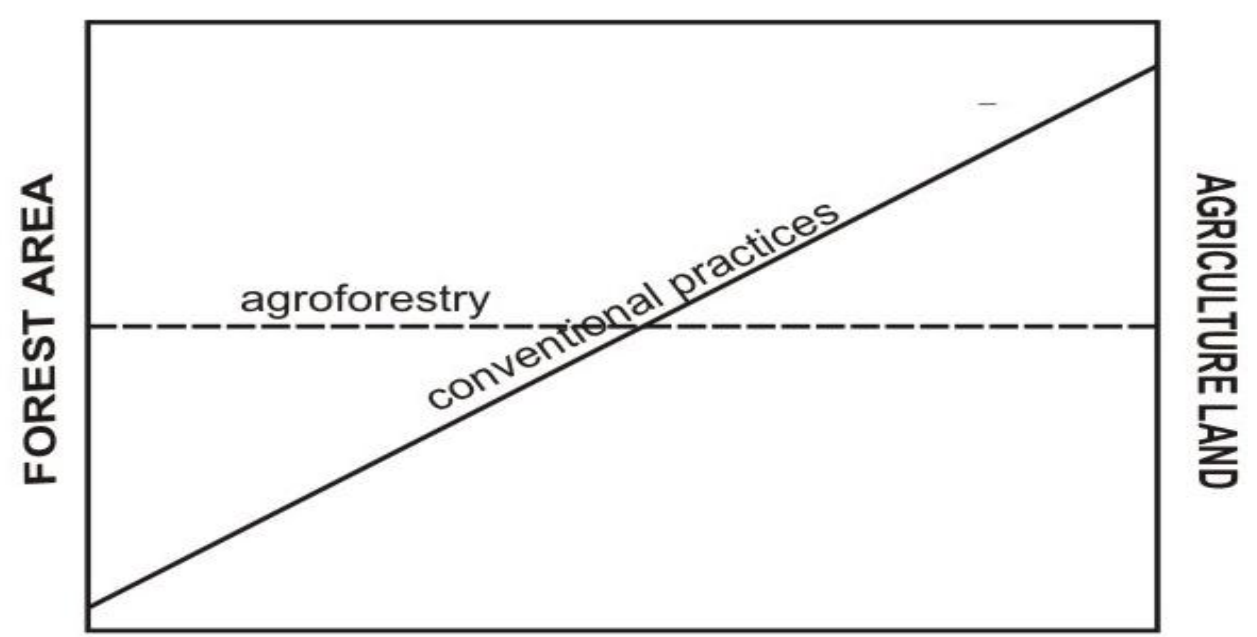

Figure 2 Perfomance of agro-forestry compared to conventional agricultural practices in relation with greener environment

\section{Material and Method}

To congregate the fore mentioned above objective data from many sources of existing situation and research accomplishment progress as well as worthy information were gathered. To provide adequate information about the potential of root crops to meet the urgent need on F6GE, inductive and deductive (Burney, 2008) approaches are executed simultaneously into convergence parity. Descriptive research method as elaborated by Hale (2013) is also employed for accomplishing better finding. These two methods can be described into activities as follows:

\subsection{Desk Study}

Eligible references related to root and tuber crops to fulfil F6GE were collected and understood clearly. References accessed from library as well as on line are executed in this study. Illegible and ambiguous information were evaluated further into detail primary as well as secondary data collected from Ministry of Agriculture, Ministry of Forestry and Indonesia Statistical Agency as well as from Food and Agriculture Organization (FAO) of United Nations (UN) and other international institutions under CGIAR such as Centro Internacional Agricultura Tropical (CIAT) Cali Columbia, Centro Internacional de la Papa (CIP) La Molina Peru, International Institute for Tropical Agriculture (IITA) Ibadan Nigeria, International Crops Research Institute for the Semi Arid Tropics (ICRISAT) Phatancheru India, Centre International Forestry Research (CIFOR) and International Centre Research for Agro-forestry (ICRAF) Bogor Indonesia. Intensive communications with the other authors' national, regional and international levels were actively built in order to clarify proper information through conferences, seminars and workshops as well as discussion via electronic mail (email) in the related field. 


\subsection{Field Observation}

To describe the fact and phenomena the observational method, field survey as well as in depth case study methods were adopted as suggested by Hale (2008) in order to obtain a better description (including prediction and explanation). Field survey was conducted by multiple visits. A series of multiple visits to root crops niche in the agro-forestry under areas of Perhutani (Forest State Enterprise) at Banten, West Java, Central Java and East Java as well as under forest managed by local communities in Sumatra, Kalimantan, Sulawesi, Nusatenggara till Papua were undertaken during 1995 to 2012. Yield cut survey in line with open ended group discussion were executed during field observation. While in depth case study was undertaken to specific case such as domain research area under Starch Research Centre, Sulusuban Lampung Ministry of Research and Technology. In depth case study was also undertaken by visiting to bio-ethanol factories in Lampung as well as in East Java which used root crops especially cassava and sweet potato as the raw materials. Experience of first author to collaborate action research for production of sweet potato in Serdang,Tanjung-Karang Lampung under Toyota Bio Indonesia, a Japanese foreign investment during 20042007 was also incorporated to obtain better accomplishment. Development sites of cassava plantation in several provinces of Indonesia especially for bio-ethanol were observed and evaluated as planned in 2007.

Comparative studies by visits to China, Thailand, Vietnam, Malaysia and India as well as EU Countries in producing bio-ethanol were also incorporated to broaden discussion. As a summary of the methods and approaches used in this study is presented below by flexible process for implementing in the real circumstances. Principally the implementation of this combination method is oriented to achieve the better accomplishment. Check and cross check is intended by focus observation to confirm in order to get valid information is simultaneously undertaken (Figure 3).

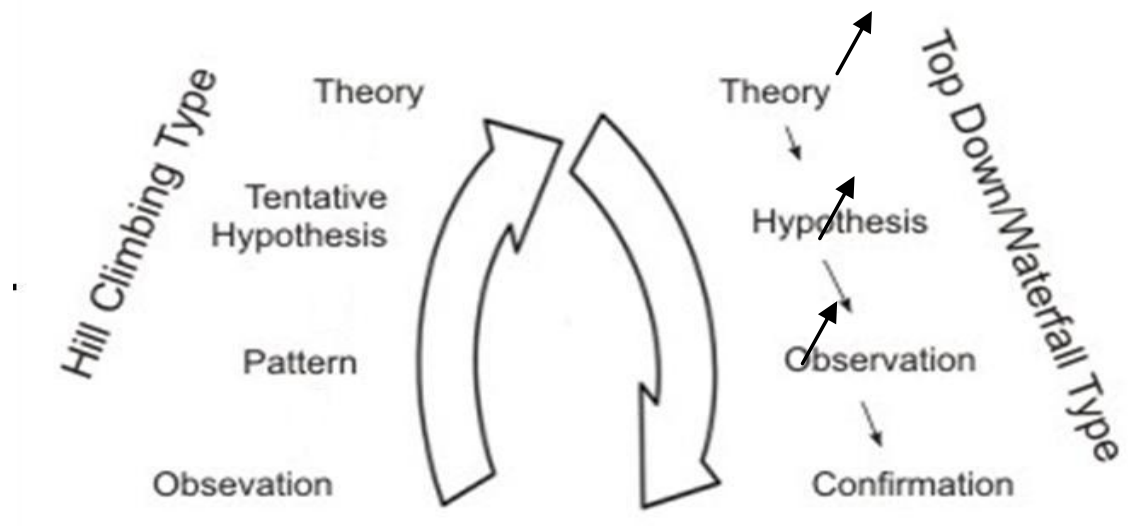

Figure 3. Relationship of Induction and Deduction Research Methods (Burney, 2008)

\section{Result and Discussion}

\subsection{Human Food and Animal Feed}

Although from its biodiversity of the root and tuber crops in Indonesia are tremendously varied, however among them only around 14 species recognized with fully utilized only two species namely cassava and sweet potato (Table 1). As consequence, current production system of root crops is mainly dominated and contributed by cassava and sweet potato. So far there is no statistical data available for the minor root and tuber crops. Although based on fact finding indicated root and tuber crops gave significant economic contribution, however a real data is not available up to recently in national till global levels. It means from agricultural census held every ten years, the potential of root and tuber crops are completely neglected. Indeed minor root and tuber crops in rural remote areas such as in outer islands still have very important contribution to the local communities as food and animal feed as well as cash income. Moreover, under hunger calamity (paceklik) root and tuber crops are the savior for the life of communities in rural remote areas as well as poor people in urban and suburban areas. 
Table 1.

Common of root and tuber crops used as food, feed and medicinal herbs in Indonesia

\begin{tabular}{|c|c|c|c|c|c|}
\hline Common name & Scientific name and Family & $\begin{array}{l}\text { Altitude } \\
\text { masl }\end{array}$ & $\begin{array}{c}\text { Temperature } \\
{ }^{\circ} \mathrm{C}\end{array}$ & $\begin{array}{c}\text { Water } \\
\text { requirement } \\
(\mathrm{mm})\end{array}$ & Specific Adaptation \\
\hline Cassava & $\begin{array}{l}\text { Manihot esculenta Crantz } \\
\text { Euphorbiaceae }\end{array}$ & $0-1400$ & $15-33$ & $500-2500$ & Humid to Arid \\
\hline Sweet potato & $\begin{array}{l}\text { Ipomea batatas (L.) Lamk } \\
\text { Convolvulaceae }\end{array}$ & $0-3000$ & $10-32$ & $500-2500$ & Humid to Semi Arid \\
\hline Yam & Dioscorea L. Dioscoreaceae & $0-2500$ & $15-32$ & $500-3.000$ & Humid to Arid \\
\hline Elephant Foot Yam & $\begin{array}{l}\text { Amorphophallus Blume ex } \\
\text { Decaisne Araceae }\end{array}$ & $0-2500$ & $12-32$ & $700-2.000$ & $\begin{array}{l}\text { Humid to Arid and shade } \\
\text { tolerant }\end{array}$ \\
\hline Taro & $\begin{array}{l}\text { Colocasia esculenta (L.) Schott } \\
\text { Araceae }\end{array}$ & $0-2700$ & $12-33$ & $700-2.000$ & Humid to Semi Arid \\
\hline Cocoyam & Xanthosoma Schott Araceae & $0-2000$ & $15-33$ & $500-2.000$ & $\begin{array}{l}\text { Humid to Arid and shade } \\
\text { tolerant }\end{array}$ \\
\hline Swampy taro & $\begin{array}{l}\text { Cyrtosperma merkusii (Hassk.) } \\
\text { Schott Araceae }\end{array}$ & $0-500$ & $22-34$ & $700-3.000$ & Arid to swampy areas \\
\hline Giant taro & Alocasia (Schott) G.Don Araceae & $0-1500$ & $20-34$ & $500-2.000$ & $\begin{array}{l}\text { Humid to Arid Shade and } \\
\text { swampy }\end{array}$ \\
\hline Cana root & Canna indica L. Cannaceae & $0-3000$ & $10-32$ & $500-1500$ & Humid to Arid shady \\
\hline Arrow Root & $\begin{array}{l}\text { Maranta arundinacea } \mathrm{L} . \\
\text { Marantaceae }\end{array}$ & $0-1000$ & $18-33$ & $500-2.000$ & Humid to Arid shady \\
\hline Java black potato & $\begin{array}{l}\text { Coleus tuberosus (Glume) } \\
\text { Benthem Labiatae }\end{array}$ & $0-1000$ & $18-33$ & $700-2.500$ & Humid to Arid \\
\hline Turmeric & $\begin{array}{l}\text { Curcuma domestica (L.) } \\
\text { Zingiberaceae }\end{array}$ & $0-1500$ & $14-32$ & $400-1500$ & Semi arid to arid shady \\
\hline Ginger & $\begin{array}{l}\text { Zingiber oficinale (L.) } \\
\text { Zingiberaceae }\end{array}$ & $0-1500$ & $14-32$ & $400-1500$ & Semi arid to arid shady \\
\hline $\begin{array}{l}\text { Galangal / aromatic } \\
\text { ginger }\end{array}$ & $\begin{array}{l}\text { Kampferia galanga (L.) } \\
\text { Zingiberaceae }\end{array}$ & $0-1500$ & $14-32$ & $400-1500$ & Semi arid to arid shady \\
\hline
\end{tabular}

Source: Widodo (1995) and Flach Rumawas (1996).

Table 2.

Distribution of cassava and sweet potato in the provinces of Indonesia 2012

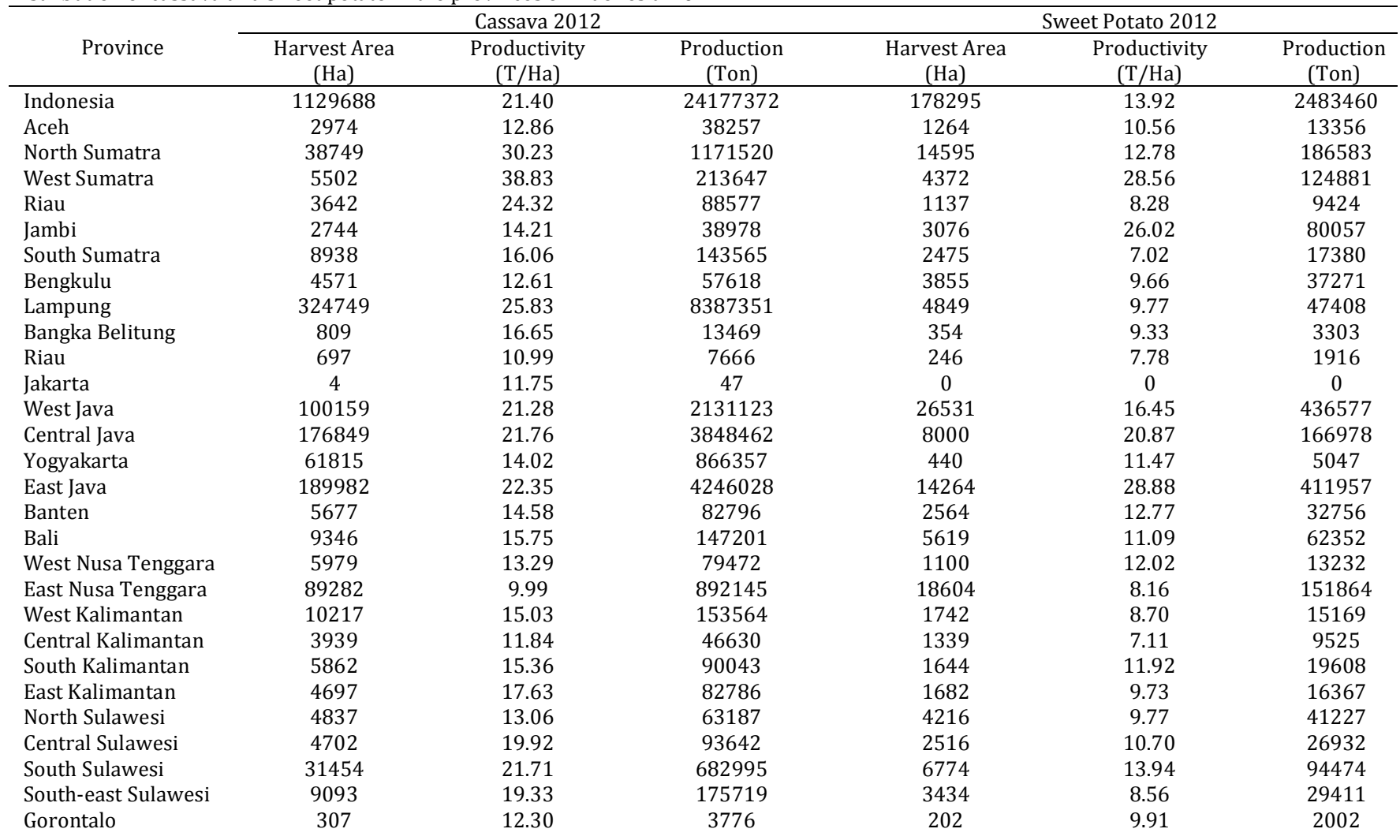


Citation: Widodo, Y., Rahayuningsih, St.A., Saleh,N., \& Wahyuningsih, S., (2014) Incorporating root crops under agro-forestry as the newly potential source of food, feed and renewable energy. Int. Journal of Renewable Energy Development, 3(3), 193-206, doi : 10.14710/ijred.3.3.193-206 $\mathrm{P}$ a g e | 198

\begin{tabular}{|c|c|c|c|c|c|c|}
\hline West Sulawesi & 2598 & 18.58 & 48265 & 1483 & 11.18 & 16589 \\
\hline Maluku & 6243 & 19.15 & 119545 & 1982 & 9.79 & 19411 \\
\hline North Maluku & 9407 & 12.39 & 116515 & 3836 & 9.03 & 34661 \\
\hline West Papua & 844 & 11.55 & 9747 & 1029 & 10.34 & 10647 \\
\hline Papua & 3020 & 12.15 & 36679 & 33071 & 10.43 & 345095 \\
\hline
\end{tabular}

Source: BPS, 2013

Although from World Food Program since 1998 suggested Indonesia to do social safety net by supporting inexpensive rice (Raskin) for the poor communities, however in some cases the quality of rice is often not feasible to be consumed by human. Therefore the poor people more prefer to consume the root and tuber crops as source of food mainly carbohydrate (Figure 4). Unfortunately the worse of situation during crisis 1998 till recently still not immediately shift the strategy to provide adequate of food. So as consequence almost every year during around Ramadan as well as Christmas the price of food is increase due to the shortage of harvest. Import of food is a way out stipulated by government in response to food shortage. Referring to food crops production from the period 1995 till 2012 indicates that among various food crops, cassava and sweet potato representing root crops have significant increase trend, especially at 2005-2011. However the increase trend on cassava is more progressive than did in sweet potato (Figure 5 and Figure 6). A cereal based on wet land rice was also criticized due to its emission of Methane and $\mathrm{N}_{2} \mathrm{O}$ (Nueu, 1993; Nguyen, 2008), so root and tuber crops which are considered ecologically friendly will play important role in the future (Green Peace, 2012). On the other hand, food stock at international market is also under uncertainty situation due to production decrease or failure harvest caused by climate change phenomenon as well as due to political conflicts and natural catastrophes. A hope for inexpensive food seems very difficult to attain Millennium Development Goals (MDGs) especially objective number 1 reduce hunger and alleviate poverty by entering 2015 (United Nation, 2008; UNDP, 2009). In the last decades, flooding during spring till early summer in Europe was also affecting to reduce agricultural production, especially food crops. Flooding is also suffered by China, India, Pakistan, Thailand, Australia, Nigeria and others, so the production of food crops decrease. Meanwhile in Africa and Mid East drought severity is a serious obstacle in the food crop production, these were worsen by political conflicts as well as inter-attack in open civil wars (Conforti and Sarris, 2011). Under such situation, Indonesia with its natural of biodiversity potential has to be able to self sufficient in food and able to contribute to nourish the global community particularly in the area recommended by World Food Program for food aid.

Definitely the potential of root and tuber crops as source of carbohydrate to realize the need of F6GE is very possible, however it should not only from current production system. It meant production system can be improved from existing as well as additional under agro-forestry (Figure 1 and Figure 2). The productivity increased by implementing the newly technology science based in the form of new high yielding cultivars as well as appropriate cultural practice is an important key. So, root and tuber crops produce from agroforestry will have significant contribution to cover the shortage of food crops from conventional agricultural lands immediately. In fact, the area of forest still provides space for root and tuber crops to be incorporated into agro-forestry system to support the food security program. Widodo (2012) reporting in Java with the forest area around $2.5 \%$ of Indonesia forest, by agro-forestry was able to contribute food crops as additional expansion agricultural sector. By intensive agro-forestry as well as conventional agriculture in Java, so the surplus production of food crops can be supplied for the community in outer islands and abroad for export to earn foreign exchange. It means that agro-forestry can be recommended into the forest area of Indonesia which still available many spaces to be utilized. Widodo and Santosa (2013) pointed out by utilizing space in between forest, landless and poor people will have an opportunity to create job especially to produce food for their own consumption as so called subsistence. Abundance of food available from agro-forestry could be processed for food related industries, feed as well as fuel for domestic and/or export. According to Widodo (2012b) shade tolerant of root crops are very suitable to be incorporated into the space under the forest stand, so carbohydrate still able to produce adequately. Starch and flour produced from root crops can be used as starter to enrich deteriorated wood to establish edible mushroom production under the forest. Elaboration from Jin tomg Peng (2010) edible mushroom is very healthy food that can be harvested daily to supply nutritious side dish for the poor. So, protein and healthy fatty acid as well as vitamin and minerals could be available adequately by developing root crops based agro-forestry by mushroom introgression.

Animal feed can be generated from root and tuber crops waste such as young stem and leaves of cassava and sweet potato. During drought period, harvesting cassava and sweet potato is very valuable for farmers, because green fodder is very nutritious for cattle, and goat husbandry. In the fish ponds of Tilapia sp in the highland of Papua as well as Gurami fish in Java, green fodder from root and tuber crops in very inexpensive source of feed. Aside green fodder from cassava and sweet potato, especially fish feed can be provided from green biomass of cocoyam, taro, aroid, yam as well as elephant food yam. The contribution of green biomass 
as fish feed has significantly contribution to reduce cost of artificial fish feed from factory till $40 \%$. It means root crops waste from its biomass can be noted as worthy animal and fish feed, which provide opportunity for the poor people generating their income.

Unlike cereals and grains which receive the huge subsidy, root crops still consider as inferior and even assumed as soil depleting factor (especially for cassava), due to during the cultivation with only minimum or no inputs et all. Typically all kinds of root crops are

harvested by digging out the root and tuber, so by this method of harvest all biomass are removed from the area. Therefore, organic fertilizer generated in the system of sustainable production system including animal dunks (from chicken to cattle) as well as sediment from fish pond have to be re-incorporated in to the land area to prevent soil depletion. In the food chain system, aside economic yield there are abundance of biomass from root and tuber crops is also used for animal and fish feed, the remaining is spent for fire wood. So ash as the source of inexpensive potash could be gathered from stoves in every household to be returned back into the field in attempts to maintain soil fertility.

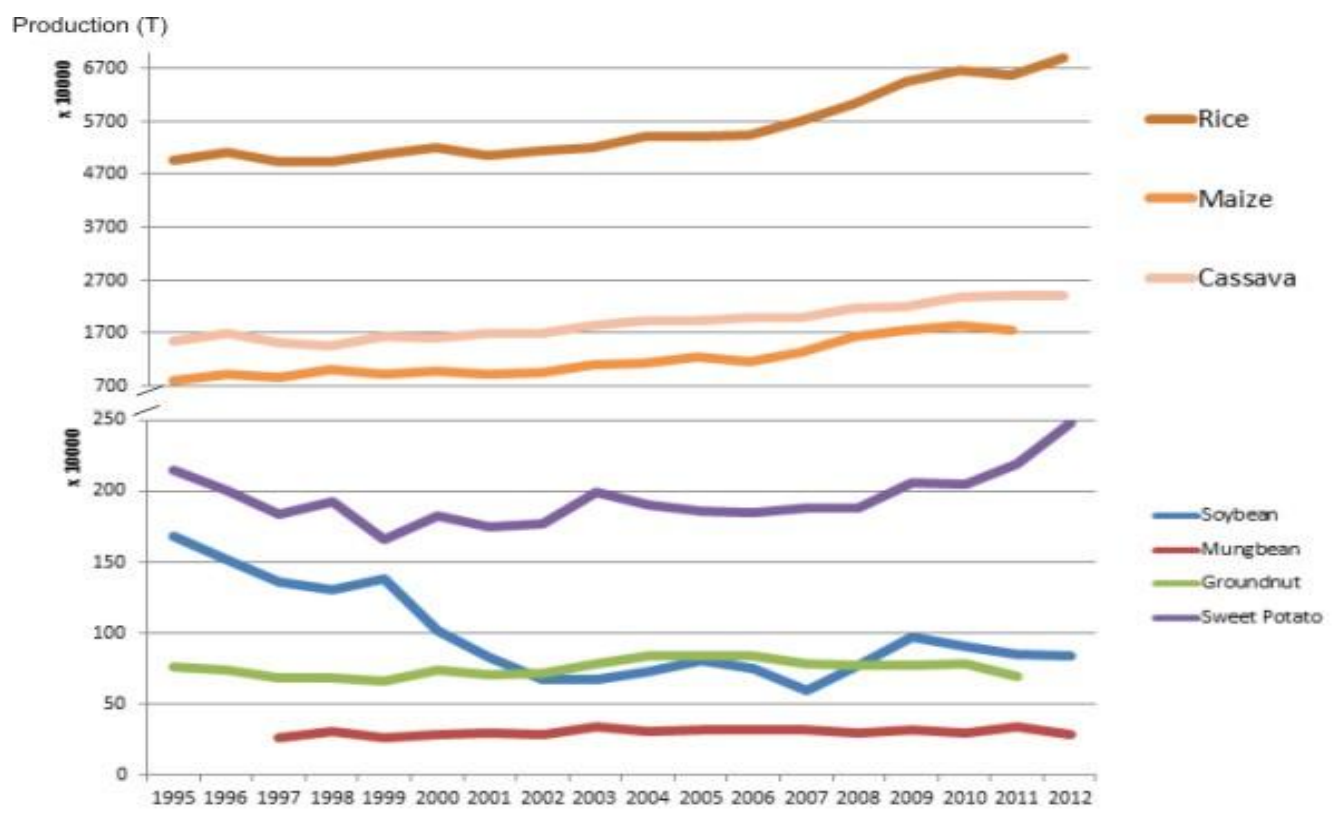

Figure 4. Production trends of various food crops in Indonesia 1995-2012.

The increase demand of cassava from domestic as well as global market was not actively responded by government to design the pattern of development with integrating sustainability approach, so there is no conflict of land area for development each commodity. Recent results in agro-forestry of cassava under teak with shade intensity $60 \%$ in Blora Central Java, the production of cassava $40 \mathrm{t} /$ ha still can be obtained (Figure 7). However for sweet potato as sun loving crop maximum shade intensity $40 \%$ can be tolerated for getting reasonable yield as in monoculture (Figure 8).

Lesson learnt from Lampung is the largest cassava area and biggest production revealed that to increase efficiency of investment no need to add the newly factories. By current situation the cassava production in Lampung is only able to fulfill $45 \%$ of raw material for industries especially starch, flour and food related industries. Expansion of planting area in Lampung and surrounding province will lead to the conversion of forest into agricultural land. It is not meet with the spirit of REDD (Reducing Emission from Deforestation and Forest Degradation), so agro-forestry is the proper way out. Intensive cassava cultivation was undertaken by farmers in Lampung by increasing the crop population and harvest around 6-8 months. Then, after harvest immediate planting is done to obtain twice harvest in year around. In the climate of tropical rain forest with rainfall > $2000 \mathrm{~mm} /$ year this cropping pattern is possible to be applied. Unfortunately climate change induces to be more difficult to predict rainfall pattern. As consequence, the production of cassava under such system is not as good as expected. Based on experience in East Java, by harvesting of cassava longer than 12 months or almost 20 months was able to withstand against rainfall anomaly amid of climate change. It means the pattern of root crops as presented in Figure 1 can be used as a guidance to cultivate properly. So, harvest late is better than harvest early, because accumulating photosynthetic results by lengthening crop duration is more effective to obtain the higher yield level. 
Citation: Widodo, Y., Rahayuningsih, St.A., Saleh,N., \& Wahyuningsih, S., (2014) Incorporating root crops under agro-forestry as the newly potential source of food, feed and renewable energy. Int. Journal of Renewable Energy Development, 3(3), 193-206, doi : 10.14710/ijred.3.3.193-206

$\mathrm{P}$ a g e $\mid 200$

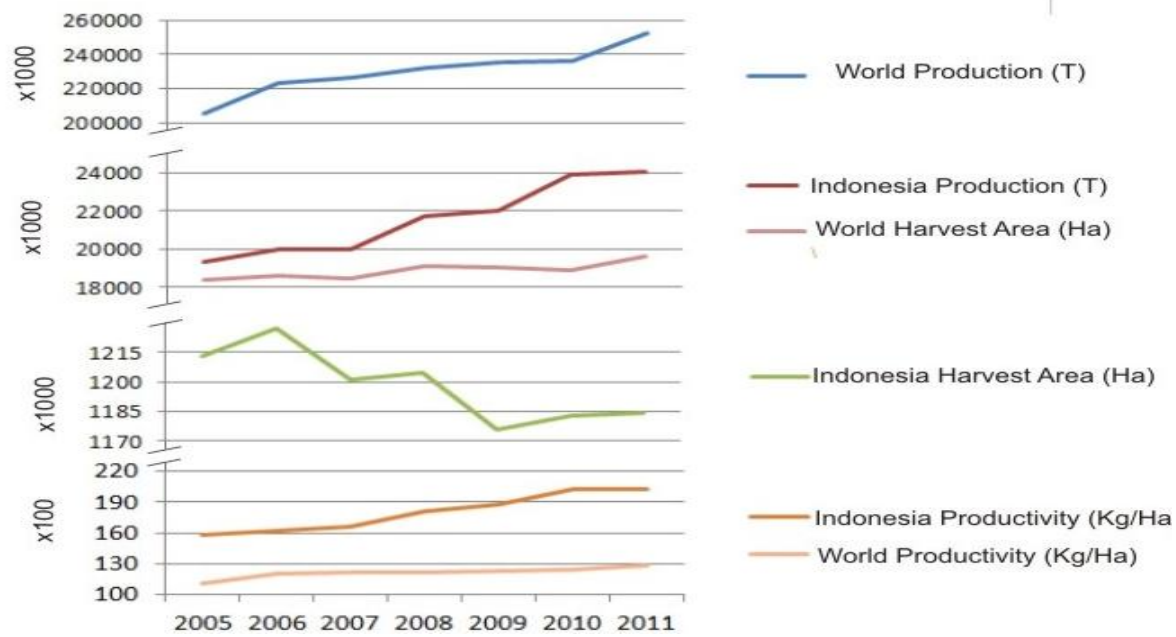

Figure 5. Trends of cassava harvest area, productivity and production in Indonesia and world 2005-2011

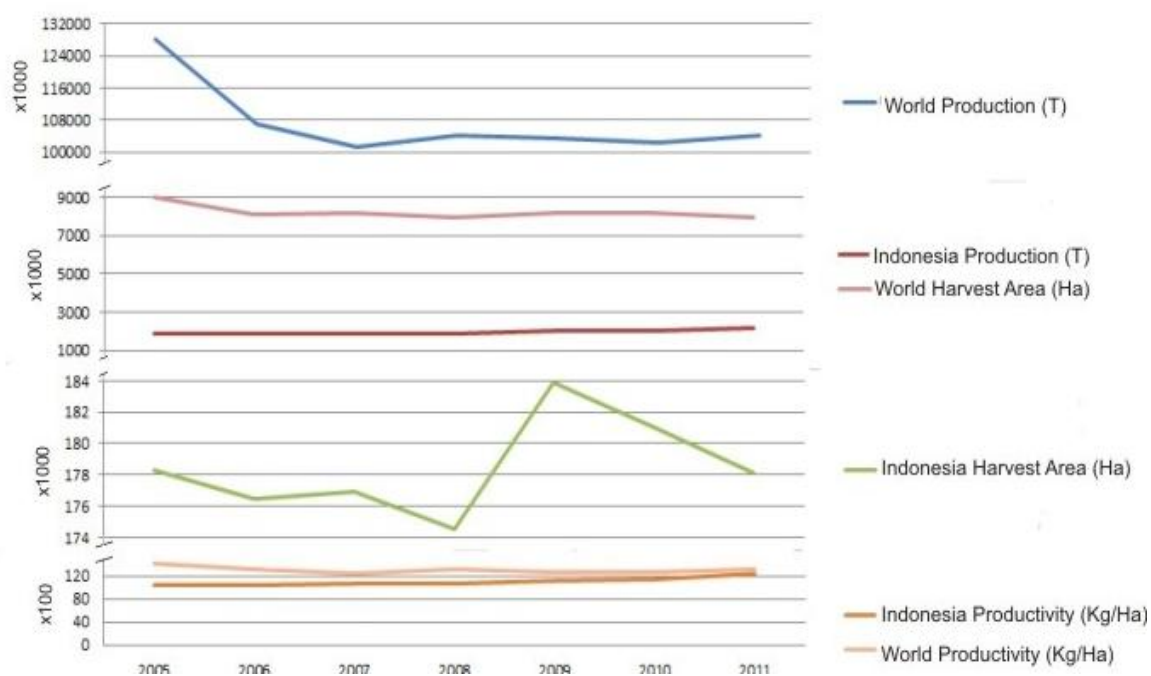

Figure 6. Trends of sweet potato harvest area, productivity and production in Indonesia and world 2005-2011.

Indeed potential of root and tuber crops was properly recognized by farmer in the complex diverse risk prone areas, therefore they always cultivate those crops as reserve of food during difficult period such as nowaday. Fortunately the progress of harvest area. Productivity as well as total production of the main root crops in Indonesia had been regularly noted (Figure 5 and Figure 6), and distribution of cassava and sweet potato in the provinces scattered in the country is also as an acurate indicator the role of those crops into economic development (Table 2). These data are reflection of the important of cassava and sweet potato in the conventional agriculture, which for expansion of those crop will face and compete to the land use with other food crop commodities. It is an important reason, therefore, to suggest agro-forestry perspective for the whole development of agricultural in broad sense meaning, including animal husbandry as well as integration of fish pond.

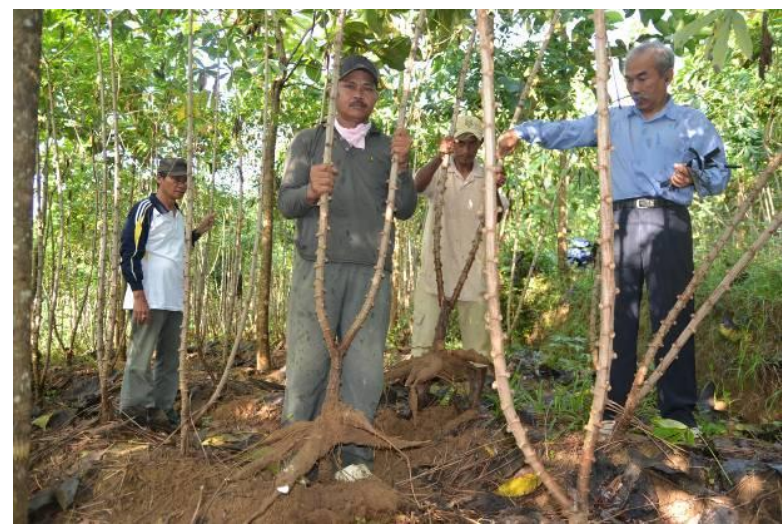

Figure 7. Cassava grown under teak with shading intensity reach almost $60 \%$. Yield around $40 \mathrm{t} /$ ha still can be obtained

There are two types of cassava namely sweet (HCN content $<50 \mathrm{ppm}$ ) and bitter (HCN content $>50 \mathrm{ppm}$ ). Sweet cassava is mostly used as table consumption without difficult preparation, so only with steam, fry, and bake or roasted then it is consumed directly. While for bitter cassava, before consume has to be removed its 
HCN by washing or sun drying. Bitter cassava is generally high in starch content; therefore it is preferred for plantation to produce starch as well as bio-ethanol. The variation of cassava cultivars is from morphological character that very wide from leaves, type of branching, color of skin and flesh as well as from biochemical aspects such as amilose and amilopectine content. In Asia at least two colors of cassava flesh, white and yellow. But in Latin America there many colors of flesh from white, yellow, orange and purple till dark purple. Varietals development of cassava in Indonesia is actively linked with Asia Program in Thailand with support of parent material from Latin America under CIAT Cassava Program. Since 1984 the authors were trained and done interdisciplinary research under collaborative coordinated program at IITA and CIAT as well. As the results there are five new high yielding cultivars had been released since 1987. Among those cultivars, two namely Adira 4 and UJ-5 are widely planted by farmers in several provinces like Lampung and whole Java. Fortunately, farmers still keep the local cultivars which have specific advantages.

Unlike cassava, in sweet potato there is no bitter variety. Unfortunately tripsin inhibitor activity and oligo saccharide are found in sweet potato, but these two substances are easily removed by heating (CIP, 2001). Aside carbohydrate sweet potato is also source of vitamin and minerals. Orange flesh color of sweet potato is rich in vitamin A equal to carrot. The content of vitamin $C$ in sweet potato is comparable with tomato fruit. While the purple flesh color indicating the content of antocyanin, the darker of purple color the higher content of antocyanin. In around Malang sweet potato with purple flesh color is very popular food presents into various snacks, noodles and ice creams. Antocyanin is useful as functional food as source of anti oxidant which its role to strengthen the heart and prevent from degenerative process. Demand of purple sweet potato flesh is not only from domestic site, but also for export to Japan, Korea and Taiwan as well. Export of sweet potato is mostly undertaken by steaming or baking then process into paste followed by frozen and keep in the container. The waste generated from sweet potato paste industry as well as the foliage is mostly for animal feed, especially dairy cattle such as in Pasuruan.

Both cassava and sweet potato for food related industries are preferred the character with high root dry matter content. To attain this specific trait, from breeding program is strongly supported by crop physiological as well as post harvest science in the interdisciplinary team. However in the practical work preparation under baking facilitated by vacuum pump to exhaust moisture is better beyond steaming. Therefore, processing sweet potato paste industry is addressed for export by implementing baking and replacing steaming method.

Leaves of cassava and sweet potato both are rich in protein, so both are used as vegetable and the remaining for animal and fish feed. In China silk-worm farm is trying to use cassava as well as sweet potato leaves as ransom to produce silk with comparable quality with the existing ransom. Preliminary study in University of Surakarta State (UNS) also revealed the used of cassava as silk-worm ransom and gave a good result to produce silk gold color fiber. It is expected the newly silk with cassava leaves based ransom will receive better price than did existing silk.

Edible plastic film in food related industries can also be generated from cassava and sweet potato starch extraction waste. Principally, both waste of starch or flour are used as substrate to be inoculated with bacteria Azetobacter zilinum such as applied in nata de coco industry. Additional of ammonium sulfate and sugar to enrich the substrate is similar as undertaken in coconut water substrate. After around 5-7 days incubation, the substrate will alter into the form of gel as so called nata de cassava or the other root crops, name depended on the main material. The quality of nata made from cassava is as good as nata from coconut. Unfortunately, nata made of cassava and the other root crops are still not well recognized, as consequence market still question mark. Except further process will be undertaken to convert nata made of cassava and the other root and tuber crops as edible plastic film, which is widely used in the food related industries.

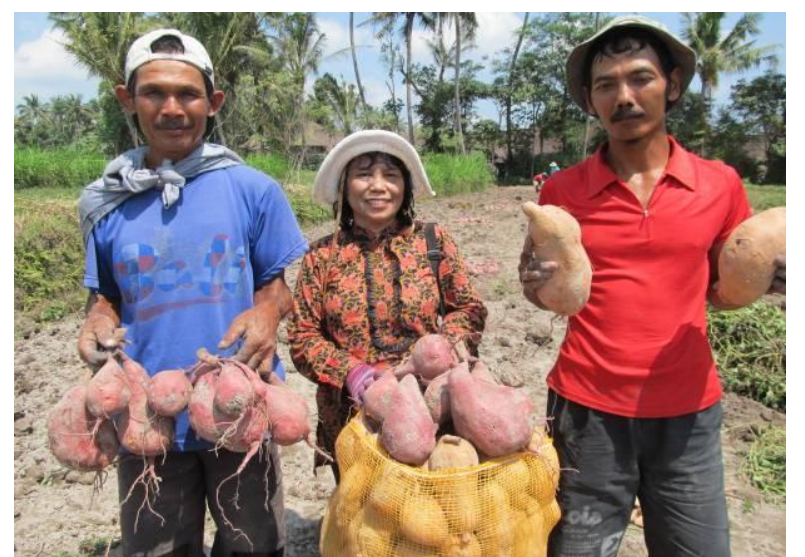

Figure 8. Sweet potato under shade intensity $<40 \%$ yield 38 $\mathrm{t} / \mathrm{ha}$ at 4 months is not difficult to attain

In minor root and tuber crops such as yam there is a very poisonous HCN in Dioscorea hispida, so to consume the tuber has to be properly treated by special treatment such as chipping, steaming, coated by ash for 3 days, washing, and drying. If during the treatment still not properly done, the poisonous food will be gained. So after eating 2-4 hours later the victim will feel head ache and motion sickness. In rural remote areas to recover from poisonous yam is by drinking coconut water. 
Citation: Widodo, Y., Rahayuningsih, St.A., Saleh,N., \& Wahyuningsih, S., (2014) Incorporating root crops under agro-forestry as the newly potential source of food, feed and renewable energy. Int. Journal of Renewable Energy Development, 3(3), 193-206, doi : 10.14710/ijred.3.3.193-206

$\mathrm{P}$ a g e $\mid 202$

\subsection{Renewable Fuel for the Greener Environment}

As elucidated in the introduction, an awareness of the need to renewable energy with ecologically friendly is an urgent necessitate. This awareness is mainly the effect of the Kyoto Protocol which more attention has been paid to the development of biomass resource use. Because, the shortage of reserve energy from the fossil at alarming situation. Indeed Indonesia after oil crisis in 2005 was starting to develop bio fuel such as Jatropha curcas, Ricinus communis, oil palm etc as source of biodiesel. Meanwhile cassava and various root and tuber crops, sugarcane, Arenga pinnata, and sweet sorghum can be developed as bio-ethanol. Unlike bio-diesel which is mostly produced from seed started at generative phase, bio-ethanol can be processed from sugar, starch as well as cellulose. It means all biomass produced from the agricultural land can be further processed into bio-ethanol. It is expected that in the near future various large scale projects of renewable energy will be implemented at the initiatives of industrialized countries through Clean Development Mechanism (CDM) scheme as recommended by Kyoto Protocol (Siregar and Sugino, 2008). Amid of the endeavor to initiate bio-fuel production, unfortunately export of cassava dried chips to China, Japan and Korea addressed as raw material of bio-ethanol for the factories overseas is still run as usual. In fact for the moment, several bio-ethanol industries in the country were not able to provide raw material of cassava. So as a consequence, they shift raw material from cassava to molasses from sugarcane.

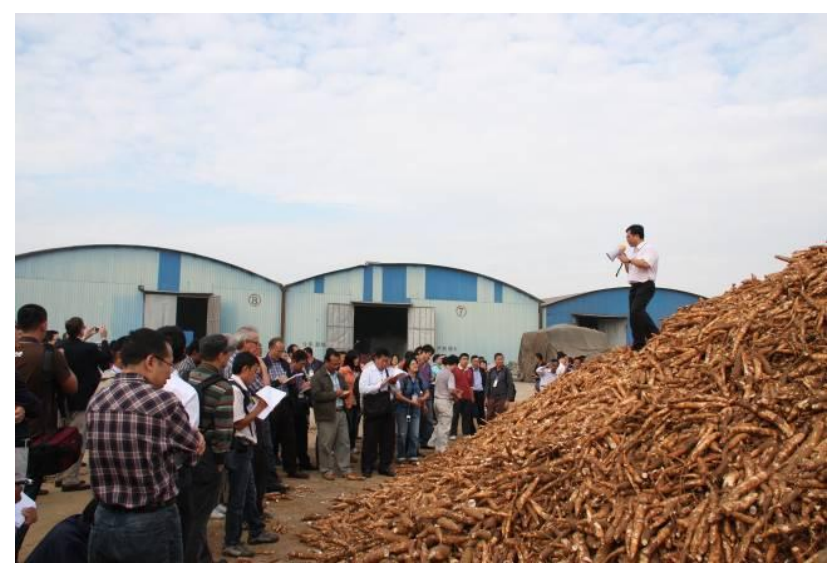

Figure 9. Mingyang Integrated Chemical Industry, Guangxi China, produces various products including starch and bio-ethanol from cassava with zero waste

Bio-ethanol production fewer had been seriously invested and started at 2005 as a response to government program in attempts to reduce the use of fossil gasoline. Small to medium scale of bio-ethanol made of cassava as well as bio-diesel from Jatropha had been established in various sites in Indonesia. Unfortunately entering 2007 this program was not continue no longer listened with the main argument was the shortage of raw material supply. Amazingly, export of raw material is still run with reasonable price. Under such condition, it seems sustainability of bio-fuel production in Indonesia is not due to a real limitation of raw materials, but due to management level. Because, the large area of Indonesia stretching along equatorial line from Sabang to Merauke is suitable for growing biomass as raw material for bio-fuel. Cost for collecting raw material is considered expensive, and this worsened by the poor infrastructure, so the price of raw material to be more expensive compared to the price at international market.

The experience of Mingyang Integrated Chemical Industry in Guangxi China, which produces various products from cassava including starch and bio-ethanol, has very efficient system. The whole processes with zero waste are completely concentrated in a large area. To sustain the operational of the factory to work year round production, cassava is always planting in the Southern of China. Cassava plantations overseas were also established in Vietnam and Indonesia, in order to support continuous supply of raw materials (Figure 9).

Rusni Distiller in Hyderabad India which produces bio-ethanol based on sweet sorghum as the main raw material is also facing the difficult problem to provide the adequacy of raw materials. Therefore, in collaboration with ICRISAT, Rusni develops raw material in the form of juice squeezed from the stem of sweet sorghum as well as from the seed of grain sorghum. The flexibility to process the liquid and solid raw material is a way out to sustain production system. It meant that the raw materials for bio-ethanol can be diversified, so it is not only based on one sort of raw material. In case of liquid feedstock, aside juice squeezed from sweet sorghum stem, sugarcane molasses can be used for supplemental or alternative. Solid raw materials can be supplied by seed of sorghum as well as other cereal grains or from cassava dry chips. By doing this strategy sustainability of bio-ethanol production system can be gradually attained. This approach was also widely implemented in Brazil as the biggest bio-ethanol producer in the world.

Since 2010 Indonesia stipulated ambitious target of bio-ethanol production at almost 4 billion l/year with raw material mainly from sugarcane, cassava and others. This production of bio-ethanol is in line with CDM under Kyoto Protocol as well as in order to gain Certificate Emission Reduction (CER) at rate of $26 \%$ by 2020. Unfortunately this program was not successfully attained, according to Siregar and Sugino (2008) there were three factors encountered. First land use planning designed by both Ministry of Agriculture and Ministry of Forestry have not yet directly linked to national bio-fuel development planning. Second, the involvement of private investors in bio-fuel development is not clear. Third, the marketing of bio-fuel products has not been established. Fortunately, investors at international level still interest to invest by improving the system of bio- 
ethanol under integrated as undertaken such as in China with supported by CDM (Bakker, 2006).

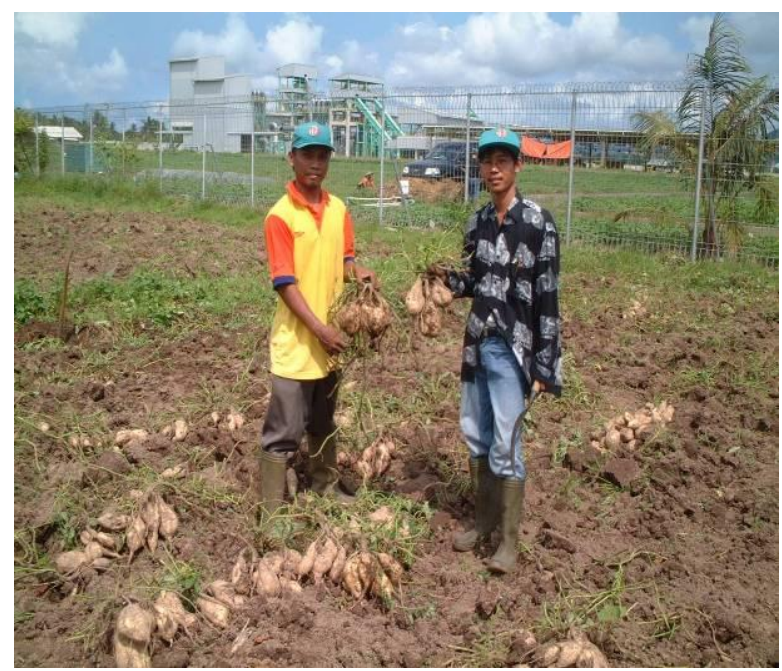

Figure 10. Sustainable production system of sweet potato for drinkable bio-ethanol (socu) is a key for sustaining the whole system (Toyota Bio Indonesia, Tanjung Karang Lampung)

In case of sweet potato, from the experiences Toyota Bio Indonesia (TBI) in Serdang, Tanjung Karang Lampung in producing drinkable bio-ethanol the most difficult problem is to provide the raw materials adequately. At large scale plantation of sweet potato productivity is around 8-12 t/ha. Pest, disease and weed as well as physiological disorders in response to acid soil are the main reason. Formerly sweet potato cultivar used by TBI was Sukuh, due to productivity of Sukuh was too low then change to Shiroyutaka. Unfortunately, alteration of cultivar was not able to solve problems. Therefore, first author was requested by TBI to investigate and prepare Standard Operational Procedure (SOP) for Good Agricultural Practices (GAP) on sweet potato. Immediately soil and plant testing for macro nutrients were undertaken to determine fertilizer amendment to be adopted under factory plantation as well as at farmers' field. Additional of dolomite with high application of potassium was significantly able to solve early leaves senescence of sweet potato Shiroyutaka and able to produce 12-18 t/ha in large areas (Figure 10). Based on this experience, it is not easy to maintain the sustainability of production system for supporting raw material of food, feed and fiber industries. Therefore, current production of root crops mainly cassava and sweet potato has to be broadening by incorporating minor root and tuber crops for fulfilling F6GE. As suggested by IFOAM (2000; 2011) as well as Green Peace (2012) small farmers with their indigenous knowledge should be recognized and implemented into the program, due to their concern to apply less fossil fuel inputs and tend to practice organic farming.

Almost every year at dry season Indonesia is blamed as smoke exporter to neighbor countries due to forest on fire. Indeed, agro-forestry is also as an appropriate way out to prevent fire in the forest. Consequently, people grown root and tuber crops under the forest will keep the crop away from fire. This method can be promoted and implemented in the fire prevention program. To be more effective in the forest fire prevention program, fish pond in between trees is also recommended.

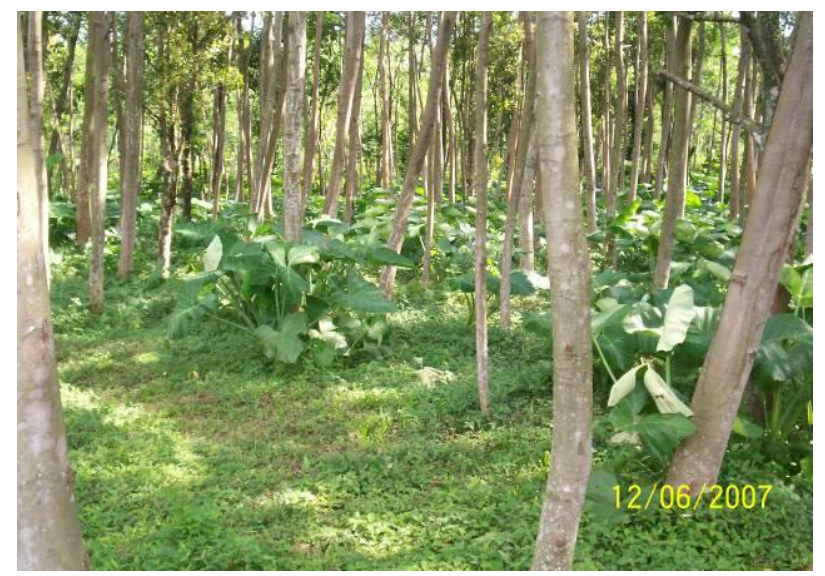

Figure 11. Shade tolerant of cocoyam suitable for agroforestry

Principally in attempts to assemble the necessary of F6GE, Indonesia is not urgently converting the forest for expanding the agricultural areas, but by implementing agro-forestry into a proper way. Shade tolerant root and tuber crops as food source food; feed and medicinal herbs can be incorporated into the forest stand, without disturbing forest as global facility to reduce $\mathrm{CO}_{2}$ emission and other glass house gases (GHG). Renewable fuel in the form of bio-ethanol could also be generated from various root and tuber crops produced under the forest stand (Table 3).

The sort of forest or plantation tree such as teak, mahoni, pines, oil palm, arenga, fast growing species, bread fruit, etc. should be planned in line with the demands domestic and international as well. Biomass in the form of lateral stems, branches till leaves could be gathered for fueling the stove of the boiler to produce electricity. The area for implementing agro-forestry is not necessary to use natural conservation forest, but it can be implemented into production forest managed by enterprises which the area available around 25 million ha (Table 4). 
Citation: Widodo, Y., Rahayuningsih, St.A., Saleh,N., \& Wahyuningsih, S., (2014) Incorporating root crops under agro-forestry as the newly potential source of food, feed and renewable energy. Int. Journal of Renewable Energy Development, 3(3), 193-206, doi : 10.14710/ijred.3.3.193-206

$\mathrm{P}$ a g e $\mid 204$

Table 3. Various species of root crops potential to be developed under agro-forestry

\begin{tabular}{lcc}
\hline \multicolumn{1}{c}{ Species of root crops } & $\begin{array}{c}\text { Tuberous } \\
\text { Root Yield } \\
\text { (t/ha/ month) }\end{array}$ & $\begin{array}{c}\text { Bio-ethanol conversion } \\
\text { rate } \\
(\mathrm{l} / \mathrm{kg})\end{array}$ \\
& & $\begin{array}{c}\text { Maximum Shade intensity } \\
(\%)\end{array}$ \\
\hline Cassava & $50-80 / 10-12$ & $1 / 6$ \\
Sweet potato & $28-46 / 4-7$ & $1 / 8.5$ \\
Elephant foot yam & $30-65 / 24-36$ & $1 / 7$ \\
Cocoyam & $32-65 / 12-24$ & $1 / 6.5$ \\
Taro & $16-35 / 8-12$ & $1 / 6.5$ \\
Yam* & $30-60 / 10-12$ & $1 / 6$ \\
Arrow Root & $12-30 / 10-12$ & $1 / 6.5$ \\
Canna Root & $15-32 / 10-12$ & $1 / 6.5$ \\
Black potato & $8-20 / 3-4$ & 82
\end{tabular}

Note* Yam has special character its vines able to climb the stem of tree to get more light intensity.

Moreover, under the oil palm, rubber, coconut etc estate crop plantation is also suitable to be utilized. As estimation the area potential for agro-forestry in Indonesia is approximately 50 million ha (Kementerian Pertanian, 2011; DJPK, 2012). By implementing agroforestry in the available area, poor landless peasants and unemployment could be alleviated, so the anxious of Mayrowani et al. (2004) as well as Setiawan (2006) can be approached and solved (Figure 11). People actively involve in the agro-forestry program could be hired from the fund generated from Carbon Trading (Carbon Initiatives World Bank, 2009). Indeed Indonesia which stretching along the equatorial line with abundance of sun shines, wave and wind, high rainfall for water dam, very spacious biodiversity to produce biomass is not feasible to suffer from hunger, poor income and lack of energy. From theory till concept for implementation is ready, only waiting to initiate the national movement by proper planning into real accomplishment. The domain for agro-forestry is available and need to be triggered to compromise ecological long term characteristic with economical short to medium purpose (Table 4)

\section{Conclusion}

Based on a series of studies and multiple observations, the conclusion elaborated is as follow:

- Current production of root and tuber crops as well as the other food crops under existing conventional agricultural production system is only able to cover the food and feed demand as well. The greater demand increased for fulfilling domestic need and for export still need the newly strategy to arrange the increase of productivity as well as expanding the harvest area.

- Agro-forestry is a compromise solution to expand agricultural land in line with forest sustainability to prevent global warming. In Indonesia still available $>50$ million hectares under production forest and estate crop (plantation) to be utilized for developing the shade tolerant root and tuber crops.

Table 4.

The area of forest managed by enterprises potential for agro-forestry, 2004-2009

\begin{tabular}{|c|c|c|c|c|c|c|}
\hline \multirow{2}{*}{ Provinces in Indonesia } & \multicolumn{6}{|c|}{ Acreage (Ha) } \\
\hline & 2004 & 2005 & 2006 & 2007 & 2008 & 2009 \\
\hline Aceh & 796723 & 524644 & 524644 & 524644 & 409644 & 409644 \\
\hline North Sumatera & 404600 & 294843 & 437393 & 328803 & 328803 & 328803 \\
\hline West Sumatera & 361430 & 268840 & 210376 & 210240 & 210240 & 194290 \\
\hline R i a u & 2390457 & 721102 & 812128 & 812128 & 715128 & 318408 \\
\hline J a m b i & 821995 & 328349 & 299974 & 133705 & 45825 & 45825 \\
\hline South Sumatera & 100000 & 56000 & 56000 & 108170 & 108170 & 108170 \\
\hline Bengkulu & 0 & 23000 & 23000 & 23000 & 23000 & 56070 \\
\hline West Nusa Tenggara & 31550 & 31550 & 31550 & 0 & 0 & 0 \\
\hline
\end{tabular}




\begin{tabular}{|c|c|c|c|c|c|c|}
\hline West Kalimantan & 1125756 & 1128860 & 1163890 & 1257670 & 1214065 & 1195570 \\
\hline Central Kalimantan & 2825221 & 4323608 & 4569645 & 4473755 & 4120635 & 4086305 \\
\hline South Kalimantan & 280811 & 320531 & 361481 & 359421 & 359361 & 279421 \\
\hline East Kalimantan & 5162452 & 6051172 & 6734227 & 6773357 & 6581712 & 6183873 \\
\hline North Sulawesi & 105500 & 60800 & 60800 & 60800 & 60800 & 60800 \\
\hline Central Sulawesi & 785270 & 1006095 & 992245 & 992245 & 902245 & 854245 \\
\hline South Sulawesi & 409965 & 293407 & 293407 & 0 & 0 & 0 \\
\hline South-east Sulawesi & 296000 & 296000 & 0 & 385590 & 385590 & 385590 \\
\hline Gorontalo & 348200 & 185570 & 185570 & 185570 & 185570 & 145000 \\
\hline West Sulawesi & 0 & 0 & 0 & 293407 & 249407 & 214245 \\
\hline M a l u ku & 818339 & 785210 & 815165 & 778865 & 554695 & 697195 \\
\hline North Maluku & 306000 & 991000 & 921675 & 983040 & 913040 & 804820 \\
\hline West Papua & 0 & 4512350 & 4350470 & 4091590 & 3560590 & 3885970 \\
\hline Papua & 4042050 & 5512253 & 5581243 & 5495043 & 5241293 & 5516643 \\
\hline Indonesia & 21412319 & 27715184 & 28424883 & 28271043 & 26169813 & 25770887 \\
\hline
\end{tabular}

Source : Forest managed by Enterprises , BPS 2012.

- Biological potential of root crops grown under agro-forestry by existing utilization is addressed for food and feed. To strengthen food sovereignty improving quality through processing is urgently required. Waste and by products could be used for feed as well for fibre.

- Renewable fuel generated from root crops under huge scale was not able to be supported from existing production system. So, increasing productivity to meet greater demand as raw material of renewable fuel has to be seriously arranged into real planning action through both conventional agricultural lands as well as mainly from agro-forestry.

- Exporting raw material of bio-fuel to supply the factories in abroad is not recommended, due to the lost of added value as well as income generation and expansion of employment. There is a strong commitment required for re-establishment of biofuel production in Indonesia which indeed the raw materials are available abundantly.

\section{Acknowledgements}

A deeply gratitude is addressed to Dr. Muslimin Nasution formerly Minister of Forestry and Steering Committee of Perhutani (State Forest Enterprise) as well as ATAS Foundation and ILETRI who provide budget for authors to accomplish this study.

\section{References}

Arrhenius, S. 1896. On the Influence of Carbonic Acid in the Air upon the Temperature of the Ground. Philosophical Magazine and Journal of Science Series 5, Volume 41, April 1896 pp 237-276. The London, Edinburgh and Dublin. PDF File down loaded from http/www.globalwarmingart.com

BPS. (1982-2012) Statistik Indonesia. Statistic Indonesia. Statistical Year Book of Indonesia 1981 to 2011. Badan Pusat Statistik Jakarta Indonesia.

Bakker, S.J.A. (2006) CDM and Biofuel: Can the CDM Assist Biofuel Production and Deployment? Energy Research Centre of the Netherlands (ECN), Petten, the Netherlands.

Burney, A. (2008) Inductive and Deductive Research Approach. Department of Computer Science, University of Karachi, Pakistan. p 22.

Carbon Initiative World Bank (2009) Carbon Initiative Help Desk World Bank. www. world bank. org. An answer of email from committee to yudi_atas@yahoo.com.

CIP. (2001) Broadening boundaries in agriculture: Impact on health habitat and hunger. International Potato Centre. Annual Report 2001. Centro Internacional de la Papa (CIP) Lima Peru. 106 p.

Conforti, P. and Sarris, A. (2011) Challenges and policies for the world agricultural and food economy in the 2050 perspective. In Global Information Early Warning System on Food and Agriculture. Food and Agriculture Organization of the United Nation (FAO) for a world without hunger. Pp 509-539.

Direktorat Jendral Planologi Kehutanan/DJPK (2012) Informasi Pemanfaatan Hutan Khususnya pada Kawasan Hutan Produksi. Sub Direktorat Penyiapan Areal Pemanfaatan Hutan. Diunduh dari www. dephut.go.id. pada tanggal 3 Desember 2012.

Eco Summit. (2007) Beijing Eco Declaration Draft. Ecological Complexity and Sustainability: Challenges and Opportunities for 21th Century's Ecology. China Academy of Sciences (CAS) Jiuhua Beijing. 4p.

Flach, M and Rumawas, F. (Eds.). (1996) Plant Resources of SouthEast Asia No 9. Plants yielding non-seed carbohydrate. Backhuys Publishers, Leiden. 237 p. 
Citation: Widodo, Y., Rahayuningsih, St.A., Saleh,N., \& Wahyuningsih, S., (2014) Incorporating root crops under agro-forestry as the newly potential source of food, feed and renewable energy. Int. Journal of Renewable Energy Development, 3(3), 193-206, doi : 10.14710/ijred.3.3.193-206

$\mathrm{P}$ a g e $\mid 206$

Food and Agriculture Organization /FAO (2012) Crops Prospect and Food Situation. FAO, Rome. No 4 p 33. December 2012.

Global Perspective Study Units, Food and Agriculture Organization of the United Nation (2006) Prospect for food nutrition agriculture and major commodity groups: World Agriculture Towards 2030/2050. FAO, Rome. 71p.

Green Peace. (2012) 1. Solution for Climate Change. 2. It's basic: smallscale farmers produce the majority of the world's food. Downloaded from website www.greenpeace. International May $1,2012$.

Hale, J. (2013) The Three Basic Types of Descriptive Research Methods. Psych Central. Retrieved on February 15, 2013, from http://psychcentral.com/blog/archives/2011/09/27/the3-basic-types-of-descriptive-research-methods/

Helimenstine, A.M. 2013. On This Day in Science History-September 29- Rudolf Diesel Mystery. About. com Chemistry. www.chemistry.about.com/September 29.2013.

IFOAM. (2000) Basic Standard for Organic Production and Processing Decided by the International Federation of Organic Agriculture Movement (IFOAM) General Assembly in Basel, Switzerland, September 2000.

IFOAM (2011) Growing Organic: Information and Resource for Developing Sustainable Organic Sector. www. ifoam.org. Downloaded February 10, 2011.

Jin-torng Peng, (2010) Overview and prospects of edible and medicinal mushrooms: production, consumption and marketing in Taiwan. Food \& Fertilizer Technology Center (FFTC) Extension Bulletin 637. 7 p

Kementerian Pertanian, (2011) Statistik Pertanian Indonesia. Pusat Data dan Sistem Informasi Pertanian. Kementerian Pertanian. Jakarta. 303 p.

MacDonald, L.H. (1982) Agro-forestry in the Africa Humid Tropics. Proc. Of a Workshop held in Ibadan Nigeria. 27 April - 1 May 1981. The United Nations University. 171p.

Mayrowani, H., Tri Pranaji, Sumaryanto, A. Agustian, Syahyuti dan R. Elizabeth, (2004) Studi prospek dan kendala penerapan reforma agraria di sektor pertanian. Pusat Penelitian dan Pengembangan Sosial Ekonomi Pertanian. Badan Penelitian dan Pengembangan Pertanian. Departemen Pertanian. Ringkasan Eksekutif. 9 p.

Neue, H.U. (1993) Methane emission from rice fields: wetland rice fields make a major contribution in global warming. Bioscience 43(7):466-73

Nguyen, N.V. (2008) Global Climate Change and Rice Food Security. Executive Secretary, International Rice Commission Food and Agriculture Organization (FAO). Rome. Pp24-30. ww.fao.org/rice/global climate (downloaded December 28, 2008).

Setiawan, B. (2006) Ekonomi Pasar yang Neo-liberalistik versus Ekonomi yang Berkeadilan Sosial. Makalah disampaikan pada Diskusi Publik "Ekonomi Pasar yang Berkeadilan Sosial" yang diadakan oleh 'Forum Komunikasi Partai Politik dan Politisi untuk Reformasi' tanggal 12 Juni 2006 di DPR-RI, Jakarta. 12 p.

Siregar, M and Sugino, T. (2008) Impact Analysus of Expanding Biomass Energy Use to Rural Poverty in Tropical Asia. CAPSA Working Paper No.103. UNESCAP-CAPSA. 61p.

Suhardjito, D., Sundawati, L., Suyanto, Utami, S.R. (2003) Aspek Sosial Ekonomi dan Budaya Agroforestri (Socio-economy Aspect in the Agro-forestry Cultivation). Bahan Ajaran Agroforestri 5. World Agrodorestry Center (ICRAF). 42p.

United Nations. (2008) The Millennium Development Goals Report. End Poverty Millennium Development Goals 2015, Make it Happen. 56p.

United Nations Development Program/UNDP. (2009) About the Millennium Development Goals Basic, What are the Millennium Development Goals? www. undp.org (downloaded February 13, 2009).

United Nations Framework Convention on Climate Change /UNFCCC. (2009) Reduction Emission from Deforestation and forest Degradation (REDD): A recommendation from Bali Road Map. www. unfccc.org (downloaded February 10, 2009).

Widodo, Y. (1995) Ubi-ubian potensi dan prospeknya untuk dimanfaatkan dalam program diversifikasi. Majalah Pangan Media Komunikasi dan Informasi Nomor 22 (VI):46-55.

Widodo. Y. (2012a) Food from the forest of Java: tropical agroforestry experiences in feeding dwellers and keeping the environment greener. In C.A, Brebbia (Ed.) SUSTAINABILITY TODAY. Wessex Institute of Technology (WIT) Press, Southampton, Boston. Printed in UK. Pp 281-393.

Widodo, Y. (2012b) Ubi-ubian dalam Wanatani: Sumbangsih Kearifan Lokal guna Mewujudkan Kedaulatan Pangan (Root crops under Agro-forestry: Contribution of Indegenous Knowledge for realizing Food Sovereignty). Dalam Buku 2 Prosiding Seminar Nasional UNS. Pp 332-353.

Widodo, Y. dan Radjit, B.S. (2013) Kinerja Wanatani: Telaah Keunggulan dari Sisi Ekonomi Kreatif (Agro-forestry Performance: Advantages Elaboration from the Side of Creative Economy). Dalam Prosiding Seminar Nasional Perhepi-UNS. Pp 372-391. 